\title{
Effect of Plant Growth Regulators in the Rooting of Pinus Cuttings
}

\author{
Andréia Henrique ${ }^{1}$, Eduardo Nogueira Campinhos ${ }^{2}$, Elizabeth Orika Ono ${ }^{3 *}$ and Sheila \\ Zambello de Pinho ${ }^{4}$ \\ ${ }^{1}$ Aracruz Celulose S.A.; Centro de Pesquisa e Tecnologia; Rodovia ES - 257; Km 25; C. P. 33.1011; 29197-000; \\ Aracruz - ES - Brasil. ${ }^{2}$ International Paper do Brasil Ltda.; Horto Mogi Guaçu; Rodovia SP 340; Km 171; \\ 13.840-970; Mogi Guaçu - SP - Brasil. ${ }^{3}$ Universidade Estadual Paulista - UNESP; Departamento de Botânica; \\ Instituto de Biociências; C.P. 510; 18618-000; eoono@ibb.unesp.br; Botucatu - SP - Brasil. ${ }^{4}$ Universidade \\ Estadual Paulista - UNESP; Departamento de Bioestatística, Instituto de Biociências; C.P. 510; 18618-000; \\ Botucatu - SP - Brasil
}

\begin{abstract}
This work evaluated the rooting of Pinus caribaea var. hondurensis Morelet cuttings under the action of different levels of plant growth regulators. The cuttings consisted of 4-6 cm long shoots of $\boldsymbol{P}$. caribaea var. hondurensis Morelet with their basal needles removed. The basal part of the cuttings were treated for 2 seconds with the following treatments: 1- NAA 2000mg L $L^{-1}$; - NAA 4000mg $L^{-1}$; 3- NAA 6000mg L ${ }^{-1}$; 4- NAA 2000mg L $L^{-1}+P B Z$

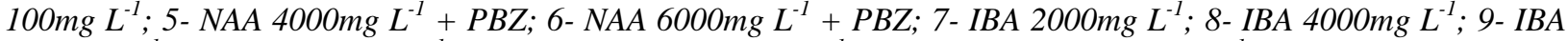
6000mg L $L^{-1}$; 10-IBA 2000mg L $L^{-1}+$ PBZ; 11-IBA 4000mg L $L^{-1}+$ PBZ; 12- IBA 6000mg L $L^{-1}+$ PBZ; and a control. After receiving the treatment, the cuttings were planted in tubes containing $50 \%$ carbonized rice hulls and $50 \%$ vermiculite. The evaluations, performed 60 days after planting, showed that $\boldsymbol{P}$. caribaea var. hondurensis cuttings treated with IBA produced a higher percentage of rooted cuttings than those treated with NAA; the most effective treatment was IBA 4000mg L $\mathrm{m}^{-1}$ plus 100mg L $\mathrm{L}^{-1}$ paclobutrazol.
\end{abstract}

Key words: Auxins, paclobutrazol, Pinus caribaea

\section{INTRODUCTION}

Cloning or vegetative propagation of trees has been a useful tool in traditional tree improvement, and the great promise of clones is for production forestry (Libby, 1986). The majority of gymnosperms, especially in the genus Pinus, are sexually propagated by seeds. With regard to large scale propagation and preservation of selected genetic characters, sexual reproduction poses a risk of loss of these characteristics. On the other hand, vegetative propagation is the form by which desired individual characteristics are maintained, resulting in a plant that is genetically identical to the original donor plant, thus becoming the preferred method of propagation (Oliveira, 1989). Conifers may be vegetatively multiplied in several different ways, for example via grafting, cuttings, adventitious shoots or somatic embryos. Comercial production of Pinus radiata by tissue culture methods is in development in New Zealand (Gleed, 1985). Propagating plants with particularly desirable characteristics is a very common practice in horticulture, used extensively with some

* Author for correspondence 
forestry species, particularly in high productivity, fiber farming systems (e.g., plantations of hybrid poplars, eucalyptus, and Caribbean pines). Rooting in Pinus cuttings depends on a series of factors that can be controlled by cutting collection time, cutting size, whether the needles are kept or not, condition and age of the source plant, plant nutritional condition, prunning, type and health of the cutting, season when the cuttings are collected, rooting-promoting treatments, condition and type of substrates, irrigation, moisture, temperature, and other factors (Silva, 1985).

The process of root formation at the base of a cutting may be divided into three stages: initiation, elongation of root initials, and root growth and development (Hartmann et al., 2002). Three groups of chemicals may be applied to regulate and/or influence the rooting process in some way: a) hormones, which induce the initial meristematic activity (Wiesman et al., 1989; Davis and Haissig, 1990) and stimulate the elongation and development of roots formed (Hartmann et al., 2002; Wiesman et al., 1989); b) nutritional elements which promote growth of the new roots (Wiesman and Lavee, 1995); c) protecting agents, such as biocides, which enable the cuttings to resist attack by pathogens during the entire rooting period.

Studies on the physiology of auxin action showed that auxin was involved in such varied plant activities as stem growth, adventitious root formation (Went, 1934; Haissig and Davis, 1994), lateral bud inhibition, abscission of leaves and fruits, and activation of cambial cells. Indole-3acetic acid (IAA) was identified as a naturally occurring compound having considerable auxin activity (Haissig and Davis, 1994). IAA was subsequently tested for its activity in promoting roots on stem segments, and in 1935, investigators demonstrated the practical use of this material in stimulating root formation on cuttings (Thimann and Koepfli, 1935). About the same time it was shown (Zimmerman and Wilcoxon, 1935) that two synthetic materials, indole-3-butyric acid (IBA) and $\alpha$-naphthalene acetic acid (NAA), were even more effective than the naturally occurring or synthetic IAA for rooting. Today, IBA and NAA are still the most widely used auxins for rooting stem cuttings and for rooting tissue-cultureproduced microcuttings. It has been repeatedly confirmed that auxin is required for initiation of adventitious roots on stems, and indeed, it has been shown that divisions of the first root initial cells are dependent upon either applied or endogenous auxins (Strömquist and Hansen, 1980; Gaspar and Hofinger, 1988). IBA has been found to occur naturally.

The formation of root primordium cells depends on the endogenous auxins in the cutting and on a synergic compound such as a diphenol. These substances lead to the synthesis of ribonucleic acid (RNA), which act upon root primordium initiation (Hartmann et al., 2002). The application of some plant growth retardants, together with auxin, has been used to improve the rooting capacity of cuttings in some species (Pan and Zhao, 1994; Wiesman and Lavee, 1995). Triazoles have been reported to affect some physiological processes during rooting (Davis and Haissig, 1990; Wiesman and Lavee, 1995). Paclobutrazol (triazol), a gibberellin synthesis inhibitor (Rademacher et al., 1984), keeps the gibberellin levels in the cuttings at low values; gibberellins are considered substances that inhibit rooting (Hartmann et al., 2002). Moreover, paclobutrazol increases the sink capacity at the base of the cutting for carbohydrates and/or hormones (Wiesman and Lavee, 1995). Thus, the objective of this work was to analyze the rooting potential of Pinus caribaea var. hondurensis Morelet cuttings under the action of different concentrations of plant growth regulators.

\section{MATERIALS AND METHODS}

Pinus caribaea var. hondurensis Morelet shoots were collected from a clonal garden. The cuttings were 4 to $6 \mathrm{~cm}$ in length with the basal needles eliminated. Later, the cuttings were treated with plant growth regulators, planted in tubes and taken to a intermitent mist system in a enclosed polyethylene propagation house for 60 days. The cuttings were treated with two auxins, indole-3butyric acid (IBA) and $\alpha$-naphthalene acetic acid (NAA), and with paclobutrazol (PBZ), by immersing the base of the cuttings in a gel solution for 2 seconds. The following treatments were used: 1- NAA 2000mg L-1; 2- NAA 4000mg L-1; 3- NAA 6000mg L ${ }^{-1}$; 4- NAA 2000mg L $\mathrm{m}^{-1}+\mathrm{PBZ}^{-1}$ 100mg L ${ }^{-1}$; 5- NAA 4000mg L ${ }^{-1}+$ PBZ; 6- NAA $6000 \mathrm{mg} \mathrm{L}^{-1}+$ PBZ; 7- IBA 2000mg L ${ }^{-1}$; 8- IBA 4000 $\mathrm{m} \mathrm{L} \mathrm{L}^{-1} ; 9-$ IBA $6000 \mathrm{mg} \mathrm{L}^{-1} ; 10-$ IBA $2000 \mathrm{mg}$ $\mathrm{L}^{-1}+$ PBZ; 11- IBA 4000mg L ${ }^{-1}+$ PBZ; 12- IBA $6000 \mathrm{mg} \mathrm{L}^{-1}+\mathrm{PBZ}$; and a control. 
After treatment, the cuttings were planted in tubes containing 50\% carbonized rice hulls and 50\% vermiculite. Evaluations were performed 60 days after planting, including: rooting percentage, total sugars contents, reducing sugars contents and phenol contents. The biochemical analyses were conducted with cutting samples on the day the experiment was started and at the end of the experiment. The total phenol content analysis in $P$. caribaea var. hondurensis cuttings was performed according to the official method prescribed by the Association of Official Analytical Chemists A.O.A.C. (1984), adapted by Skorupa et al. (1998). The total sugars and reducing sugars analyses were performed by the Somogy-Nelson method (Nelson, 1944).

The experiment was carried out as a completely randomized design with 13 treatments containing 4 replicates with 8 cuttings each. The data were submitted to analysis of variance (F test) and the means compared by Tukey test at the 5\% probability level. The data were transformed into arc sin $\operatorname{sqrt}((\mathrm{x}+0.5) / 100)$ for statistical analysis.

\section{RESULTS AND DISCUSSION}

\section{Percentage of rooted cuttings}

A significant difference in NAA concentrations (F $=19.89$ ) was observed for $P$. caribaea cuttings. The rooting percentage in the NAA $2000 \mathrm{mg} \mathrm{L}^{-1}$ treatment $(53.13 \%)$ was higher than in other treatments (Table 1), therefore, indicating that this plant growth regulator was effective in promoting rooting in cuttings of this species. NAA at 4000 and $6000 \mathrm{mg} \mathrm{L}^{-1}$ showed lower rooting percentages. The increase of NAA concentration was accompanied by the rooting percentage decrease, suggesting that high NAA concentrations were phytotoxic for the root formation process. Thus, it could be suggested that the concentration that promoted the highest rooting percentage was between 0 and $2000 \mathrm{mg} \mathrm{L}^{-1}$. Through statistical analysis, it was observed that a significant difference occurred between treatments containing IBA and the control $(\mathrm{F}=24.20)$, but no difference was observed between the different IBA concentrations used. A value of $95.31 \%$ rooted cuttings were observed at the concentration of $4000 \mathrm{mg} \mathrm{L}^{-1}$ IBA (Table 2). With regard to treatments with and without PBZ, no significant differences were observed, i.e., they did not contribute towards the root regeneration process. According to Wiesman and Lavee (1995), paclobutrazol applied in combination with IBA increased the rooting capacity of cuttings, by increasing root formation. This plant growth retardant has effects on the partition of photoassimilates, on the water status of the cuttings, and has been described as a promoter of adventitious roots in many species (Steffens and Wang, 1986). Paclobutrazol, in addition to stimulating root growth, as also mentioned by Davis et al. (1985) and Steffens and Wang (1986), increased rooting potential in this work.

Table 1 - Average rooting percentage of Pinus caribaea var. hondurensis Morelet, submitted to NAA treatments with and without the addition of paclobutrazol (PBZ).

\begin{tabular}{|c|c|c|c|}
\hline Treatments & with $\mathbf{P B Z}^{\mathbf{a}}$ & without $\mathbf{P B Z}^{\mathrm{a}}$ & Mean $^{\mathrm{a}, \mathrm{b}}$ \\
\hline Control & & & $31.25 \mathrm{~ns}$ \\
\hline NAA $2000 \mathrm{mg} \mathrm{L}^{-1}$ & 59.38 & 46.88 & $53.13 \mathrm{Ba}$ \\
\hline NAA $4000 \mathrm{mg} \mathrm{L}^{-1}$ & 18.78 & 9.38 & $14.08 \mathrm{Bb}$ \\
\hline NAA $6000 \mathrm{mg} \mathrm{L}^{-1}$ & 0.00 & 15.63 & $7.81 \mathrm{Bb}$ \\
\hline Mean & $26.05 \mathrm{~A}$ & $23.96 \mathrm{~A}$ & \\
\hline
\end{tabular}

C.V $=41.75 \%$

${ }^{\mathrm{a}}$ Means followed by different capital letters in the rows and small letters in the columns are significantly different (Tukey test at $\mathrm{p} \leq 0.05$ ); ns= non significant.

${ }^{b}$ Means followed by different capital letters in the mean column are significantly different of the table 2 mean column (Tukey test at $\mathrm{p} \leq 0.05$ ).

The percentage results of rooted cuttings treated with NAA or IBA showed that cuttings treated with IBA presented, significantly, a higher root formation response in comparison with NAA $(\mathrm{F}=$ 6.90 ), suggesting that this auxin was more effective in initiating roots in this species at these concentrations. Nelson et al. (1992), using four different auxins (IAA, IBA, NAA, and indole-3propil) in $P$. taeda, $P$. elliotti var. elliotti, and $P$. palustris showed that IAA and IBA presented 
good results, while NAA and indole-3-propil showed poorer results in the rooting of cuttings of these species. When IBA is applied to stem cuttings or microcuttings to stimulate rooting, it is, in part, converted to IAA (Vander Krieken et al., 1992). IBA may also enhance rooting via increased internal-free IBA, or may synergistically modify the action of IAA or the endogenous synthesis of IAA; IBA can enhance tissue sensitivity for IAA and increase rooting (Vander Krieken et al., 1993).

According to Hartmann et al. (2002), IBA is the best auxin for general use because it is nontoxic to plants over a wide concentration range than NAA, and is effective in promoting rooting of a large number of plant species.

\section{Total Sugars Content}

There was a significant difference between the control and the other treatments $(\mathrm{F}=18.82$ and $\mathrm{F}=$ 75.51, respectively) for $P$. caribaeae cuttings treated with either NAA or IBA. A significant interaction was also observed between NAA or IBA concentrations and the addition or not of PBZ $(\mathrm{F}=8.32$ and $\mathrm{F}=5.44$, respectively) on total sugars content.

Cuttings treated with $4000 \mathrm{mg} \mathrm{L}^{-1} \mathrm{NAA}+\mathrm{PBZ}$ and $6000 \mathrm{mg} \mathrm{L}^{-1}$ IBA showed the lowest total sugars content, while those treated with $2000 \mathrm{mg}$ $\mathrm{L}^{-1} \mathrm{NAA}$ and $4000 \mathrm{mg} \mathrm{L}^{-1} \mathrm{IBA}+\mathrm{PBZ}$ showed the highest total sugars content (Tables 3 and 4). The same treatments showed the highest rooting percentages (Tables 1 and 2). The total sugars content analysis in Pinus cuttings, immediately after they were prepared, before being placed in the rooting medium was $14.63 \%$. Thus, a reduction higher than $50 \%$ in total sugars content from the beginning of the rooting process until the evaluation period was observed, indicating the use of these sugars in the process.

\section{Reducing Sugars Contents}

The statistical analysis showed a significant difference between treatments with NAA or IBA and the control for reducing sugars content. In treatments with NAA there was a significant interaction between NAA concentrations and the presence or not of PBZ. Among the NAA treatments, $6000 \mathrm{mg} \mathrm{L}^{-1} \mathrm{NAA}$ and $2000 \mathrm{mg} \mathrm{L}^{-1}$ $\mathrm{NAA}+\mathrm{PBZ}$ showed the highest reducing sugars contents, while the lowest content was shown by the $2000 \mathrm{mg} \mathrm{L}^{-1}$ NAA treatment. The treatments containing IBA at $6000 \mathrm{mg} \mathrm{L}^{-1}$ and IBA at 2000 $\mathrm{mg} \mathrm{L}^{-1}$ showed the lowest and highest reducing sugars contents, respectively (Tables 5 and 6).

Table 2 - Mean rooting percentage of Pinus caribaea var. hondurensis Morellet cuttings, submitted to IBA treatments with and without the addition of paclobutrazol (PBZ).

\begin{tabular}{|c|c|c|c|}
\hline Treatments & with PBZ ${ }^{\mathrm{a}}$ & without PBZ $^{\mathrm{a}}$ & Mean $^{\mathrm{a}, \mathrm{b}}$ \\
\hline Control & & & $31.25 *$ \\
\hline IBA $2000 \mathrm{mg} \mathrm{L}^{-1}$ & 93.75 & 84.38 & $89.06 \mathrm{Aa}$ \\
\hline IBA $4000 \mathrm{mg} \mathrm{L}^{-1}$ & 100.00 & 90.63 & $95.31 \mathrm{Aa}$ \\
\hline IBA $6000 \mathrm{mg} \mathrm{L}^{-1}$ & 78.13 & 84.38 & $81.25 \mathrm{Aa}$ \\
\hline Mean & $90.63 \mathrm{~A}$ & $86.46 \mathrm{~A}$ & \\
\hline
\end{tabular}

C.V. $=23.11 \%$

${ }^{a}$ Means followed by different capital letters in the rows and small letters in the columns are significantly different (Tukey test at $\mathrm{p} \leq 0.05)$. *significant at $\mathrm{p} \leq 0.05$.

${ }^{\mathrm{b}}$ Means followed by different capital letters in the mean column are significantly different of the table 1 mean column (Tukey test at $\mathrm{p} \leq 0.05)$.

Table 3 - Mean total sugars contents in Pinus caribaea var. hondurensis Morelet cuttings, submitted to NAA treatments with and without the addition of paclobutrazol (PBZ).

\begin{tabular}{|c|c|c|c|}
\hline Treatments & with PBZ $^{\text {a }}$ & without PBZ $^{\text {a }}$ & Mean $^{\mathrm{a}}$ \\
\hline Control & & & $6.56^{*}$ \\
\hline NAA $2000 \mathrm{mg} \mathrm{L}^{-1}$ & $4.86 \mathrm{Ba}$ & $7.61 \mathrm{Aa}$ & 6.23 \\
\hline NAA $4000 \mathrm{mg} \mathrm{L}^{-1}$ & $3.91 \mathrm{Bb}$ & $6.81 \mathrm{Ab}$ & 5.36 \\
\hline NAA $6000 \mathrm{mg} \mathrm{L}^{-1}$ & $4.71 \mathrm{Ba}$ & $6.22 \mathrm{Ab}$ & 5.47 \\
\hline Mean & 4.49 & 6.88 & \\
\hline
\end{tabular}


Table 4 - Mean total sugars contents in Pinus caribaea var. hondurensis Morelet cuttings, submitted to IBA treatments with and without the addition of paclobutrazol (PBZ).

\begin{tabular}{|c|c|c|c|}
\hline Treatments & with PBZ $^{\mathrm{a}}$ & without $\mathbf{P B Z}^{\mathrm{a}}$ & Mean $^{a}$ \\
\hline Control & & & $6.56^{*}$ \\
\hline IBA $2000 \mathrm{mg} \mathrm{L}^{-1}$ & $5.35 \mathrm{Aa}$ & $5.28 \mathrm{Aa}$ & 5.31 \\
\hline IBA $4000 \mathrm{mg} \mathrm{L}^{-1}$ & $5.40 \mathrm{Aa}$ & $4.50 \mathrm{Bb}$ & 4.95 \\
\hline IBA $6000 \mathrm{mg} \mathrm{L}^{-1}$ & $5.27 \mathrm{Aa}$ & $4.16 \mathrm{Bb}$ & 4.71 \\
\hline Mean & 5.34 & 4.64 & \\
\hline
\end{tabular}

\section{C.V. $=6.41 \%$}

${ }^{a}$ Means followed by different capital letters in the rows and small letters in the columns are significantly different (Tukey test at $\mathrm{p} \leq 0.05)$. *significant at $\mathrm{p} \leq 0.05$.

Table 5 - Mean reducing sugars contents in Pinus caribaea var. hondurensis Morelet cuttings, submitted to NAA treatments with and without the addition of paclobutrazol (PBZ).

\begin{tabular}{|c|c|c|c|}
\hline Treatments & with PBZ $^{\mathrm{a}}$ & without $\mathbf{P B Z}^{\mathrm{a}}$ & Mean $^{\mathbf{a}}$ \\
\hline Control & & & $4.87 *$ \\
\hline NAA $2000 \mathrm{mg} \mathrm{L}^{-1}$ & $6.70 \mathrm{Aa}$ & $4.75 \mathrm{Bc}$ & 5.72 \\
\hline NAA $4000 \mathrm{mg} \mathrm{L}^{-1}$ & $5.05 \mathrm{Bb}$ & $5.71 \mathrm{Ab}$ & 5.38 \\
\hline NAA $6000 \mathrm{mg} \mathrm{L}^{-1}$ & $5.45 \mathrm{Bb}$ & $7.00 \mathrm{Aa}$ & 6.22 \\
\hline Mean & 5.73 & 5.82 & \\
\hline
\end{tabular}

\section{C.V. $=6.04 \%$}

${ }^{a}$ Means followed by different capital letters in the rows and small letters in the columns are significantly different (Tukey test at $\mathrm{p} \leq 0.05)$. *significant at $\mathrm{p} \leq 0.05$.

Table 6 - Mean reducing sugars contents in Pinus caribaea var. hondurensis Morelet cuttings, submitted to IBA treatments with and without the addition of paclobutrazol (PBZ).

\begin{tabular}{|c|c|c|c|}
\hline Treatments & with PBZ $^{\text {a }}$ & ${\text { without } \mathrm{PBZ}^{\mathrm{a}}}$ & Mean $^{\mathbf{a}}$ \\
\hline Control & & & $4.87 *$ \\
\hline IBA $2000 \mathrm{mg} \mathrm{L}^{-1}$ & 4.19 & 5.05 & $4.62 \mathrm{a}$ \\
\hline IBA $4000 \mathrm{mg} \mathrm{L}^{-1}$ & 4.11 & 4.78 & $4.44 \mathrm{ab}$ \\
\hline IBA $6000 \mathrm{mg} \mathrm{L}^{-1}$ & 3.70 & 4.14 & $3.92 \mathrm{~b}$ \\
\hline Mean & $4.00 \mathrm{~A}$ & $4.65 \mathrm{~B}$ & \\
\hline
\end{tabular}

The reducing sugars content analysis before initiation of the rooting process was $3.2 \%$; thus, a small increase in this content was observed, probably because of the conversion of total sugars, since reduction occurred, into reducing sugars.

\section{Total Phenol Contents}

The total phenol content analysis showed that apparently there was no relationship between its contents and the rooting process. In addition, the total phenol content before the rooting process, was $1.92 \%$; after the rooting process there was nearly no change in this content. The only significant difference observed was between NAA treatments, mixed or not with PBZ, where NAA alone showed the highest phenol content (Tables 7 and 8). Pandey and Pathak (1981) explained that phenols increased the action of auxins on rooting by inhibiting the IAA-oxidase system. The application of exogenous phenolic compounds can present synergism with synthetic auxins, inducing root formation.

The NAA treatments provided the greatest number of cuttings showing necrosis at the base. $P$. caribaea cuttings seemed sensitive to this auxin, while the IBA treatments, at the same concentrations, presented few cuttings showing basal necrosis. 
Table 7 - Mean total phenol contents in Pinus caribaea var. hondurensis Morelet cuttings, submitted to NAA treatments with and without the addition of paclobutrazol (PBZ).

\begin{tabular}{|c|c|c|c|}
\hline Treatments & with $\mathbf{P B Z}^{\mathrm{a}}$ & without PBZ ${ }^{\mathrm{a}}$ & Mean $^{\mathrm{a}}$ \\
\hline Control & & & $1.77 \mathrm{~ns}$ \\
\hline NAA $2000 \mathrm{mg} \mathrm{L}^{-1}$ & 1.66 & 2.08 & $1.87 \mathrm{a}$ \\
\hline NAA $4000 \mathrm{mg} \mathrm{L}^{-1}$ & 1.65 & 1.98 & $1.81 \mathrm{a}$ \\
\hline NAA $6000 \mathrm{mg} \mathrm{L}^{-1}$ & 1.65 & 1.93 & $1.79 \mathrm{a}$ \\
\hline Mean & $1.65 \mathrm{~B}$ & $1.99 \mathrm{~A}$ & \\
\hline
\end{tabular}

C.V. $=15.04 \%$

${ }^{a}$ Means followed by different capital letters in the rows and small letters in the columns are significantly different (Tukey test at $\mathrm{p} \leq 0.05)$. ns $=$ non significant.

Table 8 - Mean total phenol contents in Pinus caribaea var. hondurensis Morelet cuttings, submitted to IBA treatments with and without the addition of paclobutrazol (PBZ).

\begin{tabular}{|c|c|c|c|}
\hline Treatments & with $\mathbf{P B Z}^{\mathrm{a}}$ & without PBZ $^{\text {a }}$ & Mean $^{\mathrm{a}}$ \\
\hline Control & & & $1.77 \mathrm{~ns}$ \\
\hline IBA $2000 \mathrm{mg} \mathrm{L}^{-1}$ & 1.62 & 1.85 & $1.73 \mathrm{a}$ \\
\hline IBA $4000 \mathrm{mg} \mathrm{L}^{-1}$ & 1.88 & 1.90 & $1.89 \mathrm{a}$ \\
\hline IBA $6000 \mathrm{mg} \mathrm{L}^{-1}$ & 1.76 & 1.75 & $1.76 \mathrm{a}$ \\
\hline Mean & $1.75 \mathrm{~A}$ & $1.83 \mathrm{~A}$ & \\
\hline
\end{tabular}

\section{C.V.=14.91\%}

${ }^{a}$ Means followed by different capital letters in the rows and small letters in the columns are significantly different (Tukey test at $\mathrm{p} \leq 0.05)$. ns $=$ non significant.

In general, it was noticed that the high rooting percentages of cuttings treated with auxin coincided with higher phenolic acid contents, suggesting that Pinus cuttings with high total phenol contents had higher amounts of orthodihydroxyphenols, which decreased IAA-oxidase activity, increasing the concentration of endogenous IAA (Coll et al., 2002), therefore increasing rooting percentage. Jarvis and Shaheed (1986) reported that IAA-oxidase activity was controlled by phenolic acids (diphenols inhibit the IAA-oxidase). According to Hess (1962), the structural necessity of a phenolic component is capable of stimulating root initiation. Leopold (1964) concluded that auxin played a role on physiological processes and development, requiring other substances as rooting co-factors that would stimulate rooting, a fact also observed by Weaver (1982).

From this experiment's results it was concluded that 1) The treatment of $P$. caribaea var. hondurensis Morelet cuttings with IBA was more effective than with NAA, 2) Treatments that showed higher rooting percentages presented lower total sugars contents and higher reducing sugars contents, 3) Higher total phenol contents and higher rooting percentages were obtained in cuttings treated with plant growth regulators, 4)
The $4000 \mathrm{mg} \quad \mathrm{L}^{-1} \quad$ IBA with $100 \mathrm{mg} \quad \mathrm{L}^{-1}$ paclobutrazol treatment proved to be the most effective in promoting root formation.

A reduction in total sugars content and an increase in reducing sugars content occured, suggesting that total sugars were essential in the root formation process, and were also converted into reducing sugars. Apparently, the phenol content in this work did not influence the rooting process. The treatment of cuttings with auxins, either NAA or IBA, was required if a high rooting percentage was to be achieved, especially with IBA at $4000 \mathrm{mg} \mathrm{L}^{-1}$ + paclobutrazol at $100 \mathrm{mg} \mathrm{L}^{-1}$. Since gibberellic acid is known to inhibit root formation (Davis and Haissig, 1990), the application of anti-gibberellin growth regulators, such as paclobutrazol, together with IBA was found to enhance root formation (Davis et al., 1988; Wiesman and Riov, 1994).

\section{RESUMO}

O trabalho avaliou o enraizamento de estacas de Pinus caribaea var. hondurensis Morelet sob a ação de diferentes níveis de reguladores vegetais. As estacas foram feitas de brotações de $4 \mathrm{a} 6 \mathrm{~cm}$ de comprimento de mudas de $P$. caribaea var. hondurensis Morelet com corte bisel na base sendo 
as acículas basais eliminadas. A base das estacas foram submetidas aos tratamentos por 2 segundos com os seguintes tratamentos: 1- NAA $2000 \mathrm{mg} \mathrm{L}^{-}$ 1; 2- NAA 4000 $\mathrm{mg} \mathrm{L}^{-1}$; 3- NAA 6000mg L-1; 4NAA $2000 \mathrm{mg} \mathrm{L}^{-1}+$ PBZ $100 \mathrm{mg} \mathrm{L}^{-1}$; 5- NAA 4000mg L $\mathrm{m}^{-1}+$ PBZ; 6- NAA 6000mg L $\mathrm{L}^{-1}+$ PBZ; 7- IBA 2000mg L-1; 8- IBA 4000mg L $\mathrm{m}^{-1}$; 9- IBA 6000mg L $\mathrm{m}^{-1}$; 10-IBA 2000mg L ${ }^{-1}+$ PBZ; 11- IBA 4000 $\mathrm{m} \mathrm{L} \mathrm{L}^{-1}+$ PBZ; 12- IBA 6000mg L ${ }^{-1}+\mathrm{PBZ}_{\mathrm{e}}$ testemunha. Após os tratamentos as estacas foram plantadas em tubetes contendo $50 \%$ de palha de arroz carbonizada e $50 \%$ de vermiculita. As avaliações realizadas aos 60 dias após o plantio mostraram que estacas de $P$. caribaea tratadas com IBA levaram a maior porcentagem de estacas enraizadas que aquelas tratadas com NAA, sendo o mais efetivo, IBA a $4000 \mathrm{mg} \mathrm{L}^{-1}$ em conjunto com $100 \mathrm{mg} \mathrm{L}^{-1}$ de paclobutrazol.

\section{REFERENCES}

Altman, A. and Wareing, P. F. (1975), The sffect of IAA on sugar accumulation and basipetal transport of ${ }^{14} \mathrm{C}$-labelled assimilates in relation to root formation in Phaseolus vulgaris cutting. Physiologia Plantarum, 33, 32-38.

Coll, J. B.; Rodrigo, G. N.; García, B. S. and Tamés, R. S. (1992), Ácido abscísico y otros inhibidores. InFisiología vegetal, ed. J.B. Coll, G.N. Rodrigo, B.S. García, R.S. Tamés. Madrid: Pirámide. pp. 369-379.

Davis, T. D.; Haissig, B. E. and Sankhla, N. (1988), Effect of shoot growth retardants and inhibitors on adventitious rooting. In: Davis,T. D.; Haissig, B. E. and Sankhla, N. (Eds.). Adventitious root formation in cuttings. Portland: Dioscoride Press. pp. 174-184.

Davis, T. D. and Haissig, B.E. (1990), Chenical control of adventitious root formation in cuttings. Bulletin of Plant Growth Regulators of Society American, 18, 1-17.

Davis, T. D.; Sankhla, N.; Walser, R. et al. (1985), Promotion of adventitious root formation on cuttings by paclobutrazol. Hortscience, 20, 883-884.

Gaspar, T. and Hofinger, M. (1988), Auxin metabolism during adventitious rooting. In: Davis, T. D.; Haissig, B. E. and Sankhla, N. (Eds.). Adventitious root formation in cuttings. Portland: Dioscoride Press. pp. 61-69.

Haissig, B. E. and Davis, T. D. (1994), An historical evaluation of adventitious rooting research to 1993. In: Davis, T. D.; Haissig, B. E. (Eds.). Biology of adventitious root formation. New York: Plenum Publishing Corporation. pp. 275-331.

Hartmann, H. T.; Kester, D. E.; Davis Jr, F. T. and Geneve, R. L. (2002), Plant propagation: principles and practices. New Jersey: Prentice Hall.
Hess, C. E. (1962), Characterization of rooting co-fators estrated from Hedera helix L. and Hibiscus rosa-sinensis. In: International Horticultural Congress, 16., Toronto. Proceedings... Toronto, Canada. pp. 382-388.

Jarvis, B. C. and Shaheed, A. I. (1986), Adventitious root formation in relation to the uptake and distribution of supplied auxin. New Phytologist, 103, 23-31.

Leopold, A. C. (1964), Plant growth and development. New York: Mc Graw-Hill.

Nelson, N. (1944), A photometric adaptation of the Somogy method for determination of glucose. Journal of Biology Chemistry, 153, 375-380.

Nelson, C. D.; Linghai, Z. and Hamaker, J. M. (1992), Propagation of loblolly, slash, and Longleaf pine from needle fascicles. Tree Plant Notes, 4, 67-71.

Nordström, A. C.; Jacobs, F. A. and Eliasson, L. (1991), Effect of exogenous indole-3-acetic acid and indole-3-butiric acid on internal levels of the respective auxins and their conjugation with aspartic acid during adventitious root formation in pea cuttings. Plant Physiology, 96, 856-861.

Oliveira, E. T. (1989), Propagação vegetativa de Pinus sp via cultura de tecido. M.Sc. Dissertation, São Paulo University/ESALQ, Piracicaba, São Paulo, Brazil.

Pan, R. and Zhao, Z. (1994), Synergistic effects of plant growth retardants and IBA on the formation of adventitious roots in hypocotyl cuttings of mungbean. Plant Growth Regulators, 14, 15-19.

Pandey, D. and Pathak, R. K. (1981), Effect of Rootstocks, IBA and Phenolic Compounds on the Rooting of Apple Cuttings. Propagation of Horticulture, 13, 105-110.

Rademacher, W.; Jung, J.; Grabe, J. E.; Schwendem, L. (1984), On the mode of action of tetcyclasis and triazole growth retardants. $\mathrm{Br}$ Plant Growth Monograph, 11, 1-11.

Silva, A. A. (1985), Propagação vegetativa em Pinus spp. Silvicultura, 2, 141.

Skorupa, L. A.; Salatino, M. L. F. and Salatino, A. (1998), Hydrocarbons of leaf epicuticular waxes of Pilocarpus (Rutaceae): taxonomic meaning. Biochemical Systematics and Ecology, 26, 655-662.

Steffens, G. L. and Wang, S. Y. (1986), Biochemical and physiological alterations in apple trees caused by a giberellin biosynthesis inhibitor, paclobutrazol. Acta Horticulturae, 179, 433-442.

Strömquist, L. H. and Hansen, J. (1980), Effects of auxin of irradiance on the rooting of cuttings of Pinus sylvestris. Physiologia Plantarum, 49, 346-350.

Thimann, K. V. and Koepfli, J. B. (1935), Identity of the growth-promoting and root-forming substances of plants. Nature, 135, 101-102. 
Vander Krieken, W. M.; Breteler, H. and Visser, M. H. M. (1992), The effect of the conversion of indolebutyric acid into indoleacetic acid on root formation on microcuttings of Malus. Plant Cell Reports, 33, 709-713.

Vander Krieken, W.M.; Breteler, H.; Visser, M. H. M. and Mavridou, D. (1993), The role of the conversion of IBA into IAA on root regeneration in apple: introduction of a test system. Plant Cell Reports, 12, 203-206.

Weaver, R. J. (1982), Reguladores del Crescimento em la Agricultura. Barcelona: Trillas.

Went, F. W. (1934), A test method for rizhocaline, the rootforming substance. Proc. K. Ned. Akadem. Wet., 37, 445-455.

Wiesman, Z. and Lavee, S. (1995), Enhancement of IBA stimulatory effect on rooting of olive cultivar stem cutting. Scientia Horticulturae, 65, 189-198.

Wiesman, Z. and Riov, J. (1989), Paclobutrazol and urea-phosphate increase rooting and survival of peach "Maravilha"softwood cuttings. Hortscience, 24, 908-909.

Wiesman, Z. and Riov, J. (1994), Interaction of paclobutrazol and indole-3-butyric acid in relation to rooting of mung bean (Vigna radiata) cuttings. Physiologia Plantarum, 92, 608-612.

Zimmerman, P. W. and Wilcoxon, F. (1935), Several chemical growth substanceswhich cause initiation of roots and other responses in plants. Contrib. Boyce Thompson Inst., 7, 209-228.

Received: March 08, 2004;

Revised: January 13, 2005; Accepted: December 28, 2005. 